\title{
PREDICTION OF TEMPERATURE OF STANDARD FIRE EXPOSURE
}

\author{
Andrejus JEFIMOVAS ${ }^{a}$, Romualdas MAČIULAITIS ${ }^{\mathrm{b}}$, Donatas SIKARSKAS ${ }^{\mathrm{a}}$ \\ ${ }^{a}$ Fire Research Centre of the Fire and Rescue Department under the Ministry of the Interior, \\ Śvitrigailos str. 18, LT-03223 Vilnius, Lithuania \\ ${ }^{b}$ Vilnius Gediminas Technical University, Sauletekio av. 11, LT-10223 Vilnius, Lithuania
}

Received 05 May 2016; accepted 13 Oct 2016

\begin{abstract}
This article describes equations derived to predict the duration of local pyrolytic charring under standard fire conditions. The equations consist of five variables: electrical capacity, electrical conductivity, calorific value, depth and rate of char. The equations are split up into two groups: one for the formation of non-impregnated carbonaceous residue, and one for impregnated carbonaceous residue during pyrolysis. This means that before predicting the local duration of charring, it is necessary to determine whether the wood has been impregnated with a fire retardant solution before the fire. Electrical conductivity and electrical capacity measurement methods were used for this purpose. The temperature of standard fire local exposure is calculated by predicting the duration of local pyrolytic charring according to the standard temperature and the time dependence of fire.
\end{abstract}

Keywords: wood, fire retardants, charring, prediction.

\section{Introduction}

Wood is a material used in many areas: technique, technologies and especially in construction engineering and its products. Wood has quite a number of advantages when compared to other materials; it is strong, able to withstand heavy loads, and is a lightweight material of low thermal-conductivity, which is easily processed. However, it also has some disadvantages: it absorbs large amounts of water, deforms when exposed to moisture, and rots. The main disadvantage of wood is its relatively fast ignition and combustion. The flammability of wood can be reduced by impregnating it with fire retardants.

Many works have been devoted to research on the efficiency and durability of fire retardants (Liodakis et al. 2002; Agueda et al. 2008; Pereyra, Giudice 2009; Hagen et al. 2009; Mačiulaitis et al. 2013a). The indicators of flammability in wood impregnated with a fire retardant depend on the chemical composition of the fire retardant used (Hassan et al. 2008; Liodakis et al. 2013; Czégény et al. 2013; Arao et al. 2014; Pabelina et al. 2012), its yield, impregnation method, and the structure and characteristics of the wood (Liodakis et al. 2002; Agueda et al. 2008; Pereyra, Giudice 2009; Mačiulaitis et al. 2013b).

Fire is a complex phenomenon, and its course and effects depend on many interrelated factors (Drysdale 1998). In the event of fire in wooden buildings, or buildings with wooden structures, the most notable feature of combustion is the charring of the wooden structures. This feature is important when determining the cause of a fire, and therefore it is necessary to associate the charring of wood products and structures with other important features of fire, such as its duration or temperature (Lipinskas, Mačiulaitis 2005; Lipinskas et al. 2006). Wood is a complex material as various factors affect its pyrolysis and combustion, including flame retardants that change the wood ignition temperature and charring rate. Therefore, during a fire investigation, it is important to determine whether the wood has been impregnated with a flame retardant before the fire (Lipinskas 2006).

To determine the point of origin and causes of a fire, objective and subjective methods can be used (Lipinskas 2006). The general principles for determining the point of origin of a fire are provided in Fedotov and Megorski's work (1978), and other methodological recommendations for the officers investigating fire causes (Smirnov et al. 1986; LTEI Methodical Recommendations 1994). These sources explain how to determine where the fire started (the point of origin of the fire) based on a visual inspection of the site, data gathered from witnesses', or technical and construction documentation of the object. These investigation methods may be defined as subjective methods used for determining the most important signs of the point of origin of a fire. In the case of severe damage to identical wooden structures, the signs of burning direction can also be seen, as the depth of charring on wooden 
structures increases when approaching the fire's point of origin, because its combustion time is longer. Considering the charring rate of wood, from 0.4 to $1.2 \mathrm{~mm} / \mathrm{min}$ (Babrauskas 2004, 2005), the duration of combustion can be estimated, and this feature can be used to determine the fire's point of origin (Lipinskas 2006).

In the event of large and complex fires, data collected by using subjective, i.e. visual methods, are not enough. Additional studies using laboratory methods are needed. Such methods are called objective methods. These methods enable the use of measuring devices, which allow more accurate results to be obtained (Lipinskas 2006).

One of these methods is used in Lithuania, i.e. a method for measuring the electrical resistance of charcoal. This method was created in the Soviet Union and developed in Lithuania. The methodology is validated by the Fire Research Centre and is called 'GTC/GT 5 Fire Research Methodology - Determination of the Point of Origin of Fire in Buildings of Wooden Structures' (GTC/ GT 5 2006). With the increasing processes of charring during the fire the resistance of charcoal decreases from $10 \mathrm{G} \Omega$ to $1 \Omega$ (Lipinskas 2006).

In order to calculate the temperature and time according to GTC/GT 5 (2006), the following steps have to be carried out:

1. The reference temperature $(T, \mathrm{~K})$ has to be calculated at the place of sampling according to the following equation:

$$
T=\frac{4540}{\ln \frac{B \cdot H \cdot P}{10-P}+2.15},
$$

where: $B$ is a coefficient evaluating the thickness of the structure; $H$ - the wood char depth, mm; $P-$ the decimal logarithm of the resistivity of the coal sample.

2. The coefficient $(B)$ evaluating the thickness of the structure is calculated as follows:

$$
B=\frac{\sqrt{h}}{6},
$$

where $h$ is the initial thickness of the construction element considering the effect of heat flux, $\mathrm{mm}$.

3 . The wood char depth $(H, \mathrm{~mm})$ is calculated as follows:

$$
H=h_{a}+h_{n},
$$

where: $h_{a}$ is the carbon depth, $\mathrm{mm} ; h_{n}$ - the thickness of the burnt structure, $\mathrm{mm}$.

4. After calculation of the temperature $(T, \mathrm{~K})$ of the charred wood at the site of sampling (obtained value of temperature $T, \mathrm{~K}$ is transformed to temperature $\left.T_{s},{ }^{\circ} \mathrm{C}\right)$, the external heat flux density $\left(q_{I}, \mathrm{~kW} / \mathrm{m}^{2}\right)$ is determined as follows:

$$
q_{I}=\left(\frac{T_{S}}{99.6}\right)^{2.07},
$$

where $T_{S}$ is transformed temperature of wood charring at the site of sampling, ${ }^{\circ} \mathrm{C}$.

5 . The charring rate $(\beta, \mathrm{mm} / \mathrm{min})$ of a wooden structure is calculated at each location of sampling according to the following equation:

$$
\beta=60 \cdot \frac{1.234 q_{I}^{0.5}}{\rho\left(L_{v}+L_{w} \cdot w\right)} \cdot k_{d},
$$

where: $q_{I}$ is the external heat flux density per surface of the material from an ignition source, $\mathrm{kW} / \mathrm{m}^{2} ; \rho-$ wood density, $\mathrm{kg} / \mathrm{m}^{3} ; L_{v}-$ the amount of heat needed to evaporate the products of pyrolysis of completely dry wood, $\mathrm{kJ} / \mathrm{g} ; L_{w}$ - the heat of water evaporation equal to $2.258 \mathrm{~kJ} / \mathrm{g} ; w$ - the moisture content of wood in hundredths; $k_{d}$ - the coefficient evaluating the oxygen concentration $(=1.2)$.

6 . The indicative duration of wood charring $\left(\tau_{a}, \mathrm{~min}\right)$ is calculated according to the following equation:

$$
\tau_{a}=\frac{H}{\beta},
$$

where $H$ is the wood char depth, mm; $\beta$ - charring rate, $\mathrm{mm} / \mathrm{min}$.

7. Fire duration $\left(\tau_{b}, \min \right)$ at the site of charred wood sampling is calculated using the following equations:

$$
\begin{gathered}
\tau_{b}=\tau_{a}+\tau_{0} \\
\tau_{0}=77-0.086 T \\
\tau_{0}=94-0.101 T
\end{gathered}
$$

where: $\tau_{a}$ is wood char duration, $\min ; \tau_{o}$ - induction time, min; if wood is without protective materials, Eqn (8) is used; if wood is coated with protective materials, Eqn (9) is used.

$k_{d}=1.2$ value of the coefficient evaluating the oxygen concentration selected according to prediction equation 5 of the charring rate of wood is questionable in GTC/GT 5 methodology (2006). The coefficient is selected using the SBI (LST EN 13823:2010) test method. When testing with SBI, the sample is affected thermally by the $30.7 \pm 2.0 \mathrm{~kW}$ constant-power burner that is located at the bottom of the corner. Constant temperature is generated when wood samples are exposed to a constantpower burner, and there is also a free flow of air, which does not meet the normative standard fire conditions.

Parameter w of the moisture content of wood is used in Eqn (5) of the GTC/GT 5 methodology (2006) to calculate $\beta$, and it is not possible to determine it accurately and locally in the fire and pyrolysis zone, where the fire is extinguished using water or foam.

This method does not evaluate experimentally whether the wood has been impregnated against fire with flame retardant solutions or not.

The method for measuring electrical conductivity is used to determine the salinity of water (Moore et al. 2008). Electrical conductivity is determined by the 
concentration of sodium, potassium, calcium, magnesium, chlorine and other ions (Juozaitienè et al. 2010; Barth, Worstorff 2000; Hamann, Gyodi 2000; Hamann, Gyodi 1999). It has been assumed that in order to establish impregnation with flame retardant solutions, methods of electrical capacity or electrical conductivity can be used, because flame retardants used in Lithuania are saltbased. Data from previous studies has shown that flame retardants affect the values of the electrical conductivity and the electrical capacity, and so these methods can be used to determine the impregnation of wood (Mačiulaitis et al. 2015).

The aim of the work is to derive prediction equations for local pyrolytic char duration and, according to them, to predict the standard fire local temperature.

\section{Materials tested and testing methods}

\subsection{Materials used}

Samples of impregnated and not impregnated pine, fir wood and its carbonaceous residues pyrolysed at different times were also used. The outer layer of charred wood (carbonaceous residue) selected from sites of fire was also used for testing.

\subsection{The special one-side heating equipment}

To identify the charring peculiarities of wood from different species when heating for different periods of time and reaching different temperatures, a special chamber for one-side heating of structures was employed (Lipinskas et al. 2006; Lipinskas, Mačiulaitis 2005). This equipment ensures the simulated one-side heating of the tested specimen up to $1200{ }^{\circ} \mathrm{C}$, which is prevailing in most fires. The equipment used consisted of a one-side heating device, a heat controller, as well as instrumentation and equipment for recording measurements (Fig. 1). The principle of the experiment was to heat the specimen on one side based on the dependency of temperature on time specified in, and regulated, by LST EN 1363-1:2000. The test used up the standard temperature-time curve mathematical expression is as follows (LST ISO 834:1997):

$$
T=345 \ln (8 t+1)+20,
$$

where: $t$ is duration of the tests, min; $T$ - temperature, ${ }^{\circ} \mathrm{C}$.

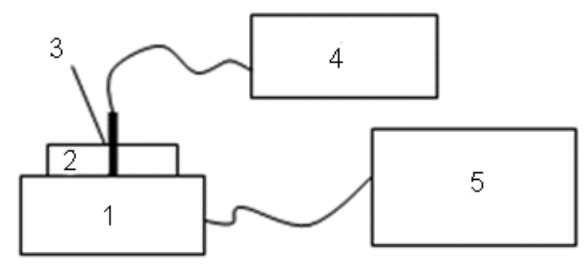

Fig. 1. The principal scheme of the one-side heating equipment that has been used for one side heating tests: 1 - the one-side heating apparatus; 2 - fragment of the tested structure; 3 the temperature measuring equipment; 4 - the Eurotherm 401 recorder; 5 - the TR-5 controller for regulation of temperature in the heating chamber
The height and width of wood specimens was $210 \mathrm{~mm}$ and $150 \mathrm{~mm}$, respectively, and the thickness varied from $47 \mathrm{~mm}$ to $59 \mathrm{~mm}$. Both natural fir and pine wood was used, as well as fir and pine wood treated with fire retardant solutions.

\subsection{Determination of charring rate and depth}

The wood char depth was measured using a calliper at the sites of fire, as shown in Figure 2, by sticking a calliper in the middle of the carbon sample until a measuring instrument reached the unburnt part of the wood. If the sample was burnt, the thickness of the burnt layer will be measured. The sum of the depth of carbon and burnt layer of the sample is called the char depth $(H, \mathrm{~mm})$.

The charring rate $\left(\beta_{s}, \mathrm{~mm} / \mathrm{min}\right)$ was selected based on previous results (Mačiulaitis et al. 2012) according to the char depth.

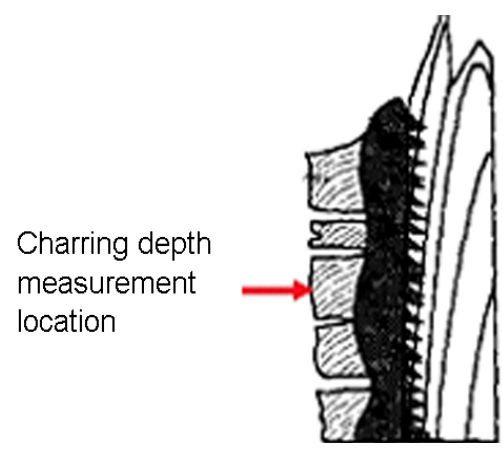

Fig. 2. Measurement of charring depth

\subsection{Determination of electrical capacity of carbon}

Equipment used for tests consisted of a device for measuring electrical capacity - RLC meter E7-13 connected by copper cables with stainless steel electrodes with a thickness of $1 \mathrm{~mm}$, width $-12 \mathrm{~mm}$, height $-30 \mathrm{~mm}$, the distance between the electrodes $-24 \mathrm{~mm}$ and the device operating frequency $-1000 \mathrm{~Hz}$.

The capacitance $(C, \mathrm{nF} / \mathrm{cm})$ of the medium (mixture) consisting of distilled water and dispersed (crushed) coal particles (having a diameter of no more than $250 \mu \mathrm{m}$ ) filled into a glass container with a diameter of $36 \mathrm{~mm}$, and a depth of $58 \mathrm{~mm}$ was measured. The composition of the medium was $50 \mathrm{~g}$ of distilled water and $0.1 \mathrm{~g}$ of the dispersed testing material (Mačiulaitis et al. 2015).

\subsection{Determination of electrical conductivity of carbon}

The medium for the measurement of electrical conductivity $(J, \mathrm{mS} / \mathrm{cm})$ was prepared by analogy. The electrical conductivity of samples was measured using a multi-meter Hanna HI4521 (Mačiulaitis et al. 2015).

\subsection{Determination of electrical resistance of carbon}

The electrical resistance $(R, \Omega)$ of each carbon sample was measured by using special equipment.

In order to measure the electric resistance of the selected carbon sample, it is necessary to comply with the 
order of priority. In particular, the surface of the samples must be clean. The mass of one sample must not be less than $1 \mathrm{~g}$.

A sample was placed in a separate open container. The container together with the sample was conditioned in the laboratory chamber furnace. The furnace temperature should not exceed $105{ }^{\circ} \mathrm{C}$. The samples must be conditioned to constant weight. Then, each sample was crushed with a pestle in the porcelain mortar. The diameter of crushed particles was less than $500 \mathrm{~mm}$.

A resistance measurement device (ohmmeter), which measures the electrical resistance $R, \Omega$ of carbon samples, was used. The press was connected to the resistance measuring device by terminals.

Then the electrical resistance of each carbon sample was measured. The sequence of this procedure was as follows: a crushed carbon specimen $(300-600 \mathrm{mg}$ ) was placed in a mould (Fig. 3) so that the original height of the mould without carbon would be increased to $4 \mathrm{~mm}$; the mould was inserted into the press and compressed mechanically (by rotating the handle) to 3500 to $5000 \mathrm{~kg} /$ $\mathrm{cm}^{2}$. Readings of the resistance-measuring device were recorded. Then, the mould was removed from the press and carbon was cleaned therefrom.
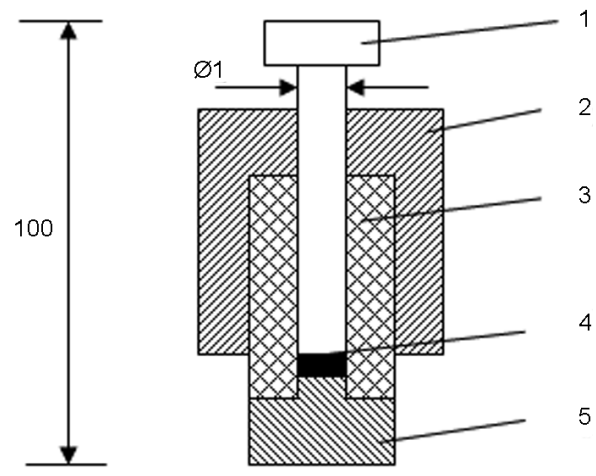

Fig. 3. Mould for char placing: 1 - plunger (HRC 55-60); 2 guide bar; 3 - ebonite insert; 4 - char; 5 - base (HRC 55-60)

\subsection{Determination of calorific value of carbon}

The resulting carbon was examined using the test method described in the standard EN ISO 1716:2010 Reaction to fire tests for products - determination of the gross heat of combustion (calorific value). The total combustion heat, which in the text below is referred to as the calorific value $(P C S, \mathrm{MJ} / \mathrm{kg})$, was determined during the tests. Special equipment was used for this purpose (Fig. 4).

\subsection{Statistical data processing}

A mathematical model with a breakpoint was used to determine the relationship between the duration of local wood charring under a modelled standard fire curve with an electrical capacity, electrical conductivity, calorific value, charring depth, and rate. The software STATISTICA 7 was used for statistical processing of experimental data (Sakalauskas 1998).

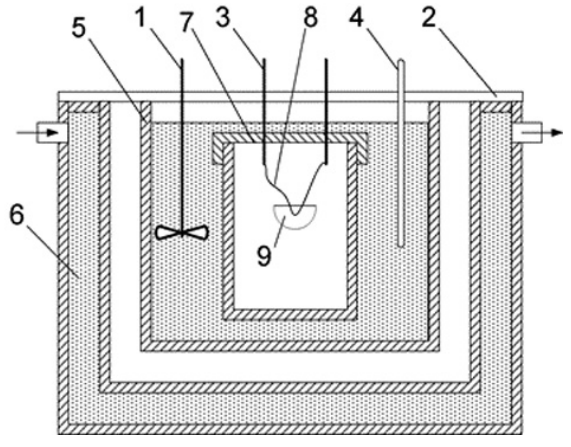

Fig. 4. Calorimeter parts: 1 - mixer for uniform mixing of water; 2 - jacket cover; 3 - fuse cables; 4 - water thermometer; 5 - calorimeter vessel; 6 - water in the jacket; 7 - calorimetric bomb; 8 - fuse wire; 9 - crucible containing the sample

\section{Research results and discussion}

Preliminary data showing the trends of the wood impregnation with flame retardants is listed in Table 1.

The pair correlation matrices from a group of carbonaceous residues from non-impregnated wood and from impregnated wood were compared according to the characteristics values of the duration of charring. The results showed (Tables 2 and 3) that the relationship between the electric capacity and electric conductivity is of opposite signs.

In the first case, this relationship was less close and directly proportional (Table 2), whereas in the second case it was closer and inversely proportional to the duration of charring (Table 3).

Meanwhile, the trends of the other three defined characteristics and values of the test time (duration of the standard fire local pyrolytic charring) and pair correlation coefficients were the same (directly proportiona), although the absolute values of those pair correlation coefficients and other characteristics were different (Tables 2,3).

This means that, before predicting the local duration of charring, it is necessary to determine whether the wood was impregnated or not with a fire retardant solution before the fire. This also means that in order to derive equations for predicting local wood charring under the said algorithm, data from both groups should be processed mathematically separately.

Equations (11)-(14) were derived for predicting the duration of local charring under a standard fire curve after processing the initial results of the two groups separately. Prediction equations of duration for formation of the nonimpregnated carbonaceous residue (Eqns (11), (12)) and impregnated carbonaceous residue (Eqns (13), (14)) during the pyrolysis were identified.

Predicting the duration by Eqns (12) and (14) using the short, but less accurate method (Eqn (12): $R=0.9939$; Eqn (14): $R=0.9701$ ), is enough to determine the electrical conductivity and the charring depth. However, in order to predict accurately the duration of charring, 
Table 1. Characteristic data of research carried out

\begin{tabular}{|c|c|c|c|c|c|}
\hline$\stackrel{t}{t}$ & $\begin{array}{c}C, \\
\mathrm{nF} / \mathrm{cm}\end{array}$ & $\begin{array}{c}J, \\
\mathrm{mS} / \mathrm{cm}\end{array}$ & $\begin{array}{l}P C S, \\
\mathrm{MJ} / \mathrm{kg}\end{array}$ & $\begin{array}{c}H, \\
\mathrm{~mm}\end{array}$ & $\begin{array}{c}\beta_{s}, \\
\mathrm{~mm} / \mathrm{min}\end{array}$ \\
\hline $5 *$ & 0.038 & 0.008 & 20.53 & 1 & 0.20 \\
\hline $5^{*}$ & 0.039 & 0.008 & 20.53 & 2 & 0.40 \\
\hline $5^{*}$ & 0.004 & 0.011 & 20.53 & 1 & 0.20 \\
\hline $5^{*}$ & 0.030 & 0.011 & 26.53 & 2 & 0.40 \\
\hline $5^{*}$ & 0.040 & 0.012 & 26.53 & 1 & 0.20 \\
\hline $5^{* *}$ & 50.000 & 0.900 & 26.13 & 1 & 0.20 \\
\hline $5^{* *}$ & 42.000 & 1.600 & 26.13 & 1 & 0.20 \\
\hline $5^{* *}$ & 40.000 & 1.200 & 26.53 & 2 & 0.40 \\
\hline $5^{* *}$ & 44.000 & 1.200 & 26.53 & 1 & 0.20 \\
\hline $5^{* *}$ & 42.000 & 1.200 & 26.53 & 2 & 0.40 \\
\hline $10^{*}$ & 0.040 & 0.011 & 30.98 & 5 & 0.50 \\
\hline $10^{*}$ & 0.043 & 0.013 & 28.72 & 4 & 0.40 \\
\hline $10^{*}$ & 0.052 & 0.015 & 29.77 & 5 & 0.50 \\
\hline $10^{*}$ & 0.011 & 0.040 & 31.07 & 4 & 0.40 \\
\hline $10^{*}$ & 0.025 & 0.050 & 30.82 & 6 & 0.60 \\
\hline $10 * *$ & 18.000 & 0.600 & 29.59 & 2 & 0.20 \\
\hline $10 * *$ & 22.000 & 0.600 & 29.25 & 1 & 0.10 \\
\hline $10 * *$ & 26.000 & 0.900 & 29.73 & 2 & 0.20 \\
\hline $10 * *$ & 18.000 & 0.800 & 30.82 & 6 & 0.60 \\
\hline $10 * *$ & 24.000 & 0.800 & 30.90 & 5 & 0.50 \\
\hline $20 *$ & 0.029 & 0.030 & 33.50 & 13 & 0.65 \\
\hline $20^{*}$ & 0.034 & 0.033 & 33.54 & 12 & 0.60 \\
\hline $20 *$ & 0.036 & 0.036 & 33.52 & 15 & 0.75 \\
\hline $20^{*}$ & 0.055 & 0.013 & 34.07 & 13 & 0.65 \\
\hline $20^{*}$ & 0.068 & 0.014 & 34.09 & 15 & 0.75 \\
\hline $20 * *$ & 12.000 & 0.400 & 33.78 & 8 & 0.40 \\
\hline $20 * *$ & 14.000 & 0.500 & 33.49 & 6 & 0.30 \\
\hline $20 * *$ & 11.000 & 0.500 & 34.50 & 13 & 0.65 \\
\hline $20 * *$ & 12.000 & 0.600 & 34.52 & 15 & 0.75 \\
\hline $20 * *$ & 13.000 & 0.700 & 34.37 & 14 & 0.70 \\
\hline $30 *$ & 0.070 & 0.020 & 33.78 & 20 & 0.67 \\
\hline $30^{*}$ & 0.055 & 0.040 & 33.50 & 23 & 0.77 \\
\hline $30^{*}$ & 0.067 & 0.030 & 33.44 & 22 & 0.73 \\
\hline $30^{*}$ & 0.069 & 0.030 & 34.49 & 25 & 0.83 \\
\hline $30 *$ & 0.073 & 0.030 & 33.75 & 22 & 0.73 \\
\hline $30 * *$ & 4.000 & 0.300 & 33.46 & 14 & 0.47 \\
\hline $30 * *$ & 4.300 & 0.500 & 33.84 & 12 & 0.40 \\
\hline $30 * *$ & 4.000 & 0.200 & 33.96 & 23 & 0.77 \\
\hline $30 * *$ & 4.500 & 0.300 & 33.95 & 23 & 0.77 \\
\hline $30 * *$ & 4.000 & 0.400 & 29.42 & 19 & 0.63 \\
\hline $45^{*}$ & 0.700 & 0.060 & 33.62 & 37 & 0.82 \\
\hline $45^{*}$ & 0.042 & 0.030 & 33.42 & 34 & 0.76 \\
\hline $45^{*}$ & 0.200 & 0.035 & 33.62 & 33 & 0.73 \\
\hline $45^{*}$ & 0.020 & 0.090 & 33.86 & 35 & 0.80 \\
\hline $45^{*}$ & 0.040 & 0.032 & 33.85 & 31 & 0.73 \\
\hline $45^{* *}$ & 1.000 & 0.100 & 34.01 & 18 & 0.40 \\
\hline $45^{* *}$ & 1.300 & 0.400 & 34.00 & 22 & 0.49 \\
\hline $45^{* *}$ & 1.800 & 0.200 & 33.63 & 35 & 0.78 \\
\hline $45^{* *}$ & 1.400 & 0.100 & 32.69 & 37 & 0.82 \\
\hline $45^{* *}$ & 2.000 & 0.200 & 32.11 & 34 & 0.76 \\
\hline
\end{tabular}

* - natural wood; ** - wood treated with fire.
Table 2. Pair correlation matrix of carbonic residual specimen group of natural wood characteristics

\begin{tabular}{c|c|c|c|c|c|c}
\hline & $t$ & $C$ & $J$ & $P C S$ & $H$ & $\beta_{s}$ \\
\hline$t$ & 1.00 & 0.51 & 0.61 & 0.71 & 0.99 & 0.82 \\
$C$ & 0.51 & 1.00 & 0.40 & 0.25 & 0.53 & 0.35 \\
$J$ & 0.61 & 0.40 & 1.00 & 0.50 & 0.62 & 0.54 \\
$P C S$ & 0.71 & 0.25 & 0.50 & 1.00 & 0.71 & 0.88 \\
$H$ & 0.99 & 0.53 & 0.62 & 0.71 & 1.00 & 0.85 \\
$\beta_{s}$ & 0.82 & 0.35 & 0.54 & 0.88 & 0.85 & 1.00 \\
\hline
\end{tabular}

prediction Eqns (11) and (13) (Eqn (11): $R=0.9984$; Eqn (13): $R=0.9958)$ must be used for the non-impregnated and impregnated wood carbonaceous residue, respectfully. However, in this case it was necessary to determine experimentally the values of five characteristics: electrical capacitance, electrical conductivity, calorific value, char depth and rate.

Table 3. Pair correlation matrix of carbonic residual specimen group of treated wood characteristics

\begin{tabular}{c|c|c|c|c|c|c}
\hline & $\mathrm{t}$ & $C$ & $J$ & $P C S$ & $H$ & $\beta_{s}$ \\
\hline$t$ & 1.00 & -0.65 & -0.76 & 0.60 & 0.95 & 0.63 \\
$C$ & -0.65 & 1.00 & 0.86 & -0.33 & -0.64 & -0.66 \\
$J$ & -0.76 & 0.86 & 1.00 & -0.47 & -0.73 & -0.63 \\
$P C S$ & 0.60 & -0.33 & -0.47 & 1.00 & 0.55 & 0.48 \\
$H$ & 0.95 & -0.64 & -0.73 & 0.55 & 1.00 & 0.78 \\
$\beta_{S}$ & 0.63 & -0.66 & -0.63 & 0.48 & 0.78 & 1.00 \\
\hline
\end{tabular}

The following prediction equations for the local pyrolytic char duration under standard fire conditions $(t$, $\min$ ) are provided for the non-impregnated wood:

$$
\begin{aligned}
t= & (0.4014-9.0834 C+9.5814 J+0.2718 P C S+ \\
& \left.1.3006 H-10.8459 \beta_{s}\right)(t \leq 22.0)+ \\
& (-12.4963-1.6268 C-7.0775 J+1.4117 P C S+ \\
& \left.1.4485 H-50.1023 \beta_{s}\right)(t>22.0) ; \\
t= & (3.5657+22.2559 J+1.1254 H)(t \leq 22.0)+ \\
& (4.3801-48.8981 J+1.2565 H)(t>22.0) .
\end{aligned}
$$

The following prediction equations for the local pyrolytic char duration under standard fire conditions $(t$, $\mathrm{min})$ are provided for the impregnated wood:

$$
\begin{aligned}
t= & (6.9628-0.0408 C-2.1147 J+0.1763 P C S+ \\
& \left.1.3405 H-14.0165 \beta_{S}\right)(t \leq 22.0)+(37.7544- \\
& 0.5757 C-1.3221 J+0.0389 P C S+ \\
& \left.1.3894 H-51.7520 \beta_{S}\right)(t>22.0) ; \\
t= & (7.8059-3.4445 J+0.9487 H)(t \leq 22.0)+ \\
& (22.2286-12.9190 J+0.7255 H)(t>22.0),
\end{aligned}
$$


where: $C$ - electrical capacity, $\mathrm{nF} / \mathrm{cm} ; J$ - electrical conductivity, $\mathrm{mS} / \mathrm{cm} ; P C S$ - calorific value, $\mathrm{MJ} / \mathrm{kg} ; H$ - char depth, $\mathrm{mm} ; \beta_{s}$ - charring rate, $\mathrm{mm} / \mathrm{min}$.

Equations (11)-(14) consisted of two parts. The first part of the equation was applied when the depth of charring of coniferous wood was $\leq 16 \mathrm{~mm}$. The second part of the equation was applied when the depth of charring of coniferous wood was $>16 \mathrm{~mm}$.

So far, the conclusion of whether the charred wood has been impregnated or not impregnated before fire has been based on documents or evidence from responsible persons. However, this is not appropriate in view of the aging process of flame retardant solutions (Grigonis et al. 2012). Therefore, the method of measuring the electrical conductivity and electrical capacity, which we have created for this purpose, is very important in order to determine more accurately the location the fire started and its causes.

If timber has been impregnated with fire-retardants before a fire, the electrical conductivity will be $\geq 0.1 \mathrm{mS} /$ $\mathrm{cm}$. Conversely, if timber has not been impregnated before a fire, the electrical conductivity will be $<0.1 \mathrm{mS} / \mathrm{cm}$. The electrical conductivity of a medium made up of impregnated charcoal and distilled water varies insignificantly when heating the timber for 30 minutes or longer, and the lowest value was $0.1 \mathrm{mS} / \mathrm{cm}$, regardless of the type, output and extinguishing method of the flame-retardant solution used in Lithuania (Mačiulaitis et al. 2015).

Additionally, the results of comparative researches are given. Based on Eqns (11) and (13), the duration of local pyrolytic charring has been calculated $(t, \mathrm{~min})$ and using equation 10 the local impact temperature of the standard fire $\left(T,{ }^{\circ} \mathrm{C}\right)$ has been determined. To compare the results, the durations and temperatures according to the GTC/GT 5 methodology (2006) (described in Section 1) have been calculated as well.

Values of data needed for calculations are given in Table 4. According to our methodology, the second part of Eqn (11) was used for the calculation of the duration of local pyrolytic charring for the first object (No. 1.1,
No. 1.2 and No. 1.3) and for the third object (No. 3.1, No. 3.2 and No. 3.3) because electrical conductivity was $<0.1 \mathrm{mS} / \mathrm{cm}$, charring depth $>16 \mathrm{~mm}$. For the second object (No. 2.1, No. 2.2 and No. 2.3) the first part of equation 13 was used because electric conductivity $>0.1 \mathrm{mS} /$ $\mathrm{cm}$, charring depth $<16 \mathrm{~mm}$. Calculation results are presented in Table 5.

Table 5 shows the predicted values of the standard local fire temperature and reference temperature at the sampling location.

Table 4. Definite values of characteristics necessary for forecasting

\begin{tabular}{c|c|c|c|c|c|c}
\hline No. & $\begin{array}{c}C, \\
\mathrm{nF} / \mathrm{cm}\end{array}$ & $\begin{array}{c}J, \\
\mathrm{mS} / \mathrm{cm}\end{array}$ & $\begin{array}{c}P C S, \\
\mathrm{MJ} / \mathrm{kg}\end{array}$ & $\begin{array}{c}H, \\
\mathrm{~mm}\end{array}$ & $\begin{array}{c}\beta_{s}, \\
\mathrm{~mm} / \mathrm{min}\end{array}$ & $\begin{array}{c}R, \\
\Omega\end{array}$ \\
\hline 1.1 & 0.28 & 0.049 & 31.75 & 53 & 0.75 & 4400000 \\
1.2 & 0.60 & 0.056 & 32.74 & 60 & 0.75 & 16700000 \\
1.3 & 0.42 & 0.045 & 32.24 & 69 & 0.75 & 143 \\
2.1 & 1.18 & 0.24 & 31.13 & 5 & 0.57 & 55000000 \\
2.2 & 1.20 & 0.34 & 32.59 & 10 & 0.65 & 24 \\
2.3 & 1.10 & 0.23 & 31.83 & 10 & 0.65 & 1131 \\
3.1 & 0.15 & 0.027 & 32.31 & 27 & 0.73 & 69 \\
3.2 & 0.28 & 0.045 & 32.86 & 31 & 0.75 & 51 \\
3.3 & 0.12 & 0.018 & 31.33 & 20 & 0.70 & 1032 \\
\hline
\end{tabular}

As we can see from the data presented in Table 5, the values of the standard fire local temperature predicted by our equations, and of the reference temperature at the sampling location predicted by the GTC/GT 5 methodology (2006), significantly differ when the charring depth is greater than $50 \mathrm{~mm}$ (Object No. 1). However, the values are similar when the charring depth ranges from 20 to $30 \mathrm{~mm}$ (Object No. 3). The greater difference between temperatures has been obtained in Object No. 2, where the depth of charring is between 5 and $10 \mathrm{~mm}$. However, unlike in Objects No. 1 and No. 3, wood (pine) in Object No. 2 was impregnated with flame retardants, and this was confirmed by electrical conductivity measurements.

Table 5. Forecasted values of time and temperature

\begin{tabular}{|c|c|c|c|c|}
\hline \multirow[b]{2}{*}{ No. } & \multicolumn{2}{|c|}{ Calculated according to our equations } & \multicolumn{2}{|c|}{ Calculated according to GTC/GT 5 (2006) } \\
\hline & $\begin{array}{l}\text { The duration of local pyrolytic } \\
\text { charring predicted by Eqns (11) } \\
\text { and (13), respectively, min }\end{array}$ & $\begin{array}{l}\text { Temperature of local stand- } \\
\text { ard fire exposure predicted } \\
\text { by Eqn }(10),{ }^{\circ} \mathrm{C}\end{array}$ & $\begin{array}{l}\text { The duration of fire at the } \\
\text { charred wood sampling loca- } \\
\text { tion, by basic Eqn (7), min }\end{array}$ & $\begin{array}{l}\text { The reference temperature } \\
\text { at the sampling location, by } \\
\text { basic Eqn }(1),{ }^{\circ} \mathrm{C}\end{array}$ \\
\hline 1.1 & 69 & 965 & 424 & 309 \\
\hline 1.2 & 78 & 983 & 551 & 282 \\
\hline 1.3 & 89 & 1004 & 280 & 476 \\
\hline 2.1 & 11 & 687 & 19 & 535 \\
\hline 2.2 & 16 & 750 & 12 & 928 \\
\hline 2.3 & 16 & 751 & 14 & 790 \\
\hline 3.1 & 35 & 866 & 74 & 887 \\
\hline 3.2 & 40 & 886 & 91 & 863 \\
\hline 3.3 & 25 & 816 & 61 & 858 \\
\hline
\end{tabular}




\section{Conclusions}

Broad and long lasting studies have shown that forecasting fire causes and locations in wooden buildings and structures is difficult and complex. It is necessary to impregnate the timber with fire retardants and experimentally confirm that fact in modern constructions.

A new and more accurate method for identifying the origin of a fire is by the prognostication of the duration of standard fire local pyrolytic charring and the impact temperature of the fire (by heating the timber from one side). For that reason, the relevant empirical equations were derived which were chosen based on the values of characteristic indicators of carbonaceous residues and the predicted duration of the local pyrolytic charring. In the next stage, the local impact temperature of the standard fire is predicted according to the duration values of local pyrolytic charring.

The complex use of the old method (GTC / GT 5 2006) and the new one created by us makes it possible to create a more accurate picture of fire development dynamics.

\section{References}

Agueda, A.; Pastor, E.; Planas, E. 2008. Different scales for studying the effectiveness of long-term forest fire retardants, Progress in Energy and Combustion Science 34(6):782796. http://dx.doi.org/10.1016/j.pecs.2008.06.001

Arao, Y.; Nakamura, S.; Tomita, Y.; Takakuwa, K.; Umemura, T.; Tanaka, T. 2014. Improvement on fire retardancy of wood flour/polypropylene composites using various fire retardants, Polymer Degradation and Stability 100: 79-85. http://dx.doi.org/10.1016/j.polymdegradstab.2013.12.022

Babrauskas, V. 2005. Charring rate of wood as a tool for fire Investigations, Fire Safety Journal 40: 528-554. https://doi.org/10.1016/j.firesaf.2005.05.006

Babrauskas, V. 2004. Wood char depth: interpretation in fire investigations, in International Symposium on Fire Investigation, 28 June 2004, Fire Service College, Moreton-inMarsh, United Kingdom. 12 p.

Barth, K.; Worstorff, H. 2000. Influence of different milking intervals on electrical conductivity before alveolar milk ejection in cows, Milchwissensch 55: 363-365.

Czégény, Z.; Jakab, E.; Blazsó, M. 2013. Pyrolysis of wood, cellulose, lignin-brominated epoxy oligomer flame retardant mixtures, Journal of Analytical and Applied Pyrolysis 103: 52-59. http://dx.doi.org/10.1016/j.jaap.2012.11.002

Drysdale, D. 1998. An introduction to fire dynamics. $2^{\text {nd }}$ ed. New York: John Wiley and Sons.

Fedotov, A. I.; Megorskij, B. V. 1978. Pozharno-mechaniceskaja ekspertiza. Moscow (in Russian).

Grigonis, M.; Mačiulaitis, R.; Praniauskas, V. 2012. Ageing of fire coatings, International Review of Civil Engineering 3(1): 71-78.

GTC/GT 5. 2006. Gaisro kilimo vietos nustatymas mediniu konstrukciju pastatuose [Determination of the point of origin of fire in buildings of wooden structures]. Fire Research Centre of the Fire and Rescue Department under the Ministry of the Interior (in Lithuanian).

Hagen, M.; Hereid, J.; Delichatsios, M. A.; Zhang, J.; Bakirtzis, D. 2009. Flammability assessment of fire-retarded Nordic Spruce wood using thermogravimetric analyses and conecalorimetry, Fire Safety Journal 44: 1053-1066. https://doi.org/10.1016/j.firesaf.2009.07.004
Hamann, J.; Gyodi, P. 1999. Electrical conductivity in fraction-collected quarter milk samples with low somatic cell counts, Milchwissensch 54: 487-491.

Hamann, J.; Gyodi, P. 2000. Somatic cells and electrical conductivity in relation to milking frequency, Milchwissensch 55: 303-307.

Hassan, M. A.; Kozlowski, R.; Obidzinski, B. 2008. New FireProtective Intumescent Coatings for Wood, Journal of Applied Polymer Science 110(1): 83-90. https://doi.org/10.1002/app.28518

Juozaitienè, V.; Šlapkauskaitè, J.; Tušas, S.; Brazauskas, A.; Japertienè, R. 2010. Kintančio elektrinio pieno laidumo melžimo fazėse tyrimai ir ryšys su karvių produktyvumu ir somatinių ląstelių skaičiumi piene [Electrical conductivity changes of milk during milking phase with cows productivity and somatic cells count], Veterinarija ir zootechnika 51: 23-29 (in Lithuanian).

Liodakis, S.; Tsapara, V.; Agiovlasitis, I. P.; Vorisis, D. 2013. Thermal analysis of Pinus sylvestris L. wood samples treated with a new gel-mineral mixture of short- and longterm fire retardants, Thermochimica Acta 568: 156-160. http://dx.doi.org/10.1016/j.tca.2013.06.011

Liodakis, S.; Bakirtzis, D.; Lois, E.; Gakis, D. 2002. The effect of $\left(\mathrm{NH}_{4}\right)_{2} \mathrm{HPO}_{4}$ and $\left(\mathrm{NH}_{4}\right)_{2} \mathrm{SO}_{4}$ on the spontaneous ignition properties of Pinus halepensis pine needles, Fire Safety Journal 37(5): 481-494. http://dx.doi.org/10.1016/S0379-7112(02)00008-5

Lipinskas, D. 2006. Gaisro kilimo vietos nustatymas pagal mediniu konstrukciju apanglejima [Prediction of fire origin location to wood materials charring]: Dissertation's thesis. Vilnius Gediminas Technical University (in Lithuanian).

Lipinskas, D.; Mačiulaitis, R.; Lukošius, K. 2006. Singularity and importance of determination of wood charring rate in fire investigation, Journal of Materials Science 12(1): 42-47.

Lipinskas, D.; Mačiulaitis, R. 2005. Further opportunities for development of the method for fire origin prognosis, Journal of Civil Engineering and Management 11(4): 299-307. http://dx.doi.org/10.1080/13923730.2005.9636361

LTEI metodinès rekomendacijos. 1994. Gaisravietès apžiūra ir techninès gaisru ekspertizès skyrimas [LTEI methodical recommendations. Fire origin inspection and technical fires expertise appointment]. Vilnius (in Lithuanian).

LST EN 13823:2010 Reaction to fire tests for building products - Building products excluding floorings exposed to the thermal attack by a single burning item. Lithuanian Standard.

LST EN ISO 1716:2010 Reaction to fire tests for products Determination of the gross heat of combustion (calorific value). Lithuanian Standard.

LST EN 1363-1:2000 Fire resistance tests - Part 1: General requirements. Lithuanian Standard.

LST ISO 834:1997 Fire-resistance tests - Elements of building products. Lithuanian Standard.

Mačiulaitis, R.; Jefimovas, A.; Zdanevičius, P. 2012. Research of natural wood combustion and charring processes, Journal of Civil Engineering and Management 8(5): 631-641. http://dx.doi.org/10.3846/13923730.2012.720935

Mačiulaitis, R.; Praniauskas, P.; Yakovlev, G. 2013a. Research into the fire properties of wood products most frequently used in construction, Journal of Civil Engineering and Management 19(4): 573-582. http://dx.doi.org/10.3846/13923730.2013.810169

Mačiulaitis, R.; Jefimovas, A.; Sikarskas, D. 2013b. Research of charring and resulting char in natural and treated timber, International Review of Civil Engineering 4(4): 155-161.

Mačiulaitis, R.; Jefimovas, A.; Lipinskas D. 2015. Research of electrical capacitance and electrical conductivity of char 
resulting from natural and treated wood, Journal of Civil Engineering and Management 21(1): 11-20.

http://dx.doi.org/10.3846/13923730.2014.941922

Moore, R. D.; Richards, G.; Story, A. 2008. Electrical conductivity as an indicator of water chemistry and hydrologic process, Watershed Management Bulletin 11(2): 25-29.

Pabelina, K. G.; Lumban, C. O.; Ramos, H. J. 2012. Plasma impregnation of wood with fire retardants, Nuclear Instruments and Methods in Physics Research 272: 365-369. https://doi.org/10.1016/j.nimb.2011.01.102
Pereyra, A. M.; Giudice, C. A. 2009. Flame-retardant impregnants for woods based on alkaline silicates, Fire Safety Journal 44(4): 497-503. http://dx.doi.org/10.1016/j.firesaf.2008.10.004

Sakalauskas, V. 1998. Statistika su Statistica [Statistics with Statistica]. Vilnius: Margi raštai (in Lithuanian).

Smirnov, K. P.; Cheshko, I. D.; Jegorov, B. S.; Tolstych, B. I. 1986. Kompleksnaja metodika opredelenija ochaga pozhara. Leningrad: VNIIPO (in Russian).

Andrejus JEFIMOVAS. Doctor of Technological Sciences. He works at the Fire Research Centre of the Fire and Rescue Department under the Ministry of the Interior, Lithuania. Research interests: fire resistance and flammability research of building materials.

Romualdas MAČIULAITIS. Prof. Doctor Habil. of Technological Sciences. Research interests: development of building materials and analysis of their characteristics.

Donatas SIKARSKAS. He works at the Fire Research Centre of the Fire and Rescue Department under the Ministry of the Interior, Lithuania. Research interests: fire resistance and flammability research of building materials. 